\title{
Reformers and Revolutionaries in Modern Iran
}

\author{
Stephanie Cronin, ed. \\ London and New York: Routledge, 2009. 316 pages.
}

One cannot think of politicized Islam in Iran without thinking of the Iranian Left's formation and overall history. The awkward yet symbiotic relationship between them continues to impact how political decisions are made, especially at the parliamentary level. Given the Left's wide-ranging linkages with surrounding regions, including the Causacus (early twentieth century) and the Arab Middle East (particularly during the 1970s), experts dealing with those regions' politics would benefit from this work. As one of the Middle East's strongest leftist movements before the 1980s, any discussion of neighboring revolutionary movements must at least consider it. Although this book assumes familiarity with twentieth-century Iran's secular politics and might be considered too dense, its rather large bibliographic section is meant to encourage individual intellectual pursuits.

Many contemporary scholars of the Iranian Left agree on its adherents' general lack of critical self-reflection throughout the twentieth century. Reformers and Revolutionaries in Modern Iran offers a forum for critical reassessments of organizational platforms along with constructive propositions meant to enhance the viability of left-leaning programs - especially social-democratic initiatives. This latter point is crucial, because several contributors deliberately state the importance of rejuvenating the Left through social democratic reformism. Historical examples are used to prove this option's viability over the more "rigid" Marxist-Leninist and Stalinist examples.

Fred Halliday contextualizes the Iranian Left's history within a broader geopolitical scope, explaining how some unique manifestations within it (e.g., its acquiescence to Allied belligerence during the Second World War) can be rooted in a broader context. His dismissal of Islamic approaches to social change by calling its cognate thinking an "intellectual jail" (p. 33) is, however, quite disheartening. Afshin Matin-asgari's brief overview of the movement's trajectory as it developed during the twentieth century contains the first sustained endorsement of the social democratic option. The article asserts that we are currently witnessing a return to the social democratic ideals once espoused by early twentieth-century social critics in the Caucasus. As mentioned earlier, there is an explicit bias in favor of this option throughout much of the text. 
As evinced in her "The Iranian Constitutional Revolution, 1906-11," Janet Afary's keen insight into the role played by non-Muslim revolutionaries during the constitutional era is brought out in her contribution. The genealogy behind the all-important workers councils, their auxiliary militias, the proliferation of printed periodicals, and the relations between prominent Muslim politicians such as Hasan Taqizadah and non-Muslim supporters are excellently detailed.

While Afary delves deep into the archives of the constitutional movement's formation, Pezhmann Dailami goes a step further by describing the alteration of socioeconomic circumstances that led to the creation of a nascent socialist movement. The emigration of Iranian peasants and artisans to Azerbaijan during the economic downturn of the late nineteenth century is a relatively unexploited stage in Iranian history. It served a crucial role, however, in the Edalat Party's transformation into the Iranian Communist Party during the 1920s. The lethargy of Baku's working class and the diligence of full-time revolutionaries such as Haider Khan Amu-Ughly reflect a general trend that would be repeated often throughout the twentieth century.

Stephanie Cronin highlights Haider Khan's collusion with Major Abulqasim Lahuti during the takeover of Iranian Azerbaijan in 1922. This event was emblematic of Iran's unruly state of affairs prior to Reza Khan's autocratic crackdown. One important juxtaposition here is that between the Gendarmes and the Soviet-backed Cossacks Brigade. The direction taken by the provisional leadership in early 1922 reflects the cadres' general sense of autonomy, which echoes Halliday's claim regarding the Left's relative autonomy during some crucial moments in its history. While there were moments of relative autonomy, Touraj Atabaki details the tragic treatment of Iranian communists in the USSR during the first half of the twentieth century, with the Stalinist purges being the most devastating episode. Ehsanollah Khan came to represent a stock of revolutionaries who needed to be rehabilitated by Moscow years after being struck down by a storm of conflicting allegiances.

Homa Katouzian's portrayal of Khalil Maleki as an inspirational "precursor" (p. 165) to parliamentary socialism runs parallel with the book's general thrust. Maleki's split from the rigidity of the dominant Communist Party of the time and his theoretical formulations (especially his "third force in general/particular" theory) represent a form of independence and originality that is said to have been lacking among the movement's more ultra-Leftist elements. During the 1970s, those guerrilla organizations that endorsed armed struggle epitomized this latter tendency. Maziar Behrooz illustrates this stage 
of the Iranian Left's history. As the only article dedicated to this unique period, however, it would have been interesting to read about this branch's redemptive qualities to supplement the overwhelming endorsement of reformist strategies.

As one of the most prominent feminist scholars of the far Left, Haideh Moghissi analyzes the Left's catastrophic failure to properly handle the grievances of Iranian women. This failure is related, in part, to the disconnect that exists between the base and the leadership of leftist organizations. This disconnect is brought out more clearly in her other article, coauthored by Saeed Rahnema, which reveals the sense of alienation between the working class and the leftist leadership. Both authors clearly outline the confusion in organizational analyses of the composition of Iran's working class and ignorance of the nuances and particularities of the Iranian milieu even after all these years of exile. Both this confusion and a general misunderstanding of surrounding phenomena, including the Islamist movement's precise character, serve as the basis for what Ali Mirsepassi calls "the tragedy of the Iranian Left" (p. 229) and Saeed Rahnema's turn toward a constructive and deliberative path through social democratic theorization.

Beyond the discussion surrounding the Left's failure, one of its collateral successes is its continuing ability to radicalize the Islamic movement. Ever since its formal inception in Iran, this effect has been unrelenting. Even today, as many of the contributors pointed out, social democratic elements are infiltrating the leftist ranks of the Islamic Republic. Although, as Ervand Abrahamian asserts, the reform movement's most prominent members are influenced by liberal discourse, the permanence of leftist influence cannot easily be shaken off. 